\title{
THE EFFECTIVENESS OF DISINFECTION METHODS ON GERMINATION OF GOJI SEEDS (Lycium barbarum L.) IN IN VITRO CULTURE
}

\section{WPŁYW ZASTOSOWANYCH METOD DEZYNFEKCJI NA ZDOLNOŚĆ KIEŁKOWANIA NASION JAGODY GOJI (Lycium barbarum L.) W KULTURACH IN VITRO}

\author{
Department of Horticulture, West Pomeranian University of Technology, Szczecin, Poland \\ ${ }^{1}$ Department of Plant Genetics, Breeding and Biotechnology, West Pomeranian University \\ of Technology, Szczecin
}

\begin{abstract}
Streszczenie. Do skutecznego usuwania patogenów i mikroorganizmów z powierzchni materiału roślinnego $\mathrm{w}$ kulturach in vitro stosuje się odpowiednio dobrane metody dezynfekcji. Alternatywnym rozwiązaniem do powszechnie stosowanych środków chemicznych jest ozonowanie. Porównano efektywność dezynfekcji nasion dwóch odmian goi 'A' i 'New Big' powszechnie stosowanymi środkami chemicznymi: $\mathrm{NaOCl}(7 \%, 10 \%$ i $15 \%)$ oraz $\mathrm{HgCl}_{2}(0,2 \%)$ z metodą ozonowania na sucho i mokro w czasie 5 i 15 min. Najwyższy procent skiełkowanych nasion odmian 'A' i 'New Big' (odpowiednio 62\% i 78\%), przy najmniejszej liczbie zakażeń (odpowiednio $8 \%$ i 14\%), uzyskano po zastosowaniu $7 \%$ NaOCl. Mniej skuteczny był roztwór $0,2 \% \mathrm{HgCl}_{2}$, po zastosowaniu którego procent skiełkowanych nasion odmian ' $A$ ' i 'New Big' był niższy (odpowiednio 37\% i 30\%). Natomiast po zastosowaniu ozonowania eksplantatów 'A' i 'New Big' na mokro przez 15 min uzyskano najwyższy procent skiełkowanych nasion (w przypadku odmiany ' $A$ ' - $47 \%$, a w przypadku odmiany 'New Big' - 53\%); sterylność kultur u odmiany ' $A$ ' wynosiła $100 \%$. Ponadto ozonowanie nasion wykazało podobną efektywność dezynfekcji jak zastosowanie 15-procentowego roztworu $\mathrm{NaOCl}$. W związku z tym stosowanie ozonowania na sucho może stanowić alternatywną metodę dezynfekcji.
\end{abstract}

Key words: goji berry, $\mathrm{HgCl}_{2}$, Lycium barabarum L., $\mathrm{NaOCl}$, ozone, tissue culture.

Słowa kluczowe: $\mathrm{HgCl}_{2}$, jagoda goji, kultury tkankowe, Lycium barbarum L., $\mathrm{NaOCl}$, ozonowanie.

\section{INTRODUCTION}

Lycium barbarum L. is commonly known as goji berry. It is a spiked, perennial shrub belonging to the family of Solanaceae. It comes from the north-western parts of China (Osman et al. 2013). Fruits of goji berry are round or oval, red or orange with a large number of seeds. L. barbarum $L$. berries contain multiple mineral and organic compounds (vitamins $B_{1}, B_{6}, A, C, E$ ), with the potential of repairing epidermal damage and showing excellent effects on the cardiovascular and cholesterol levels (Dănăilă-Guidea et al. 2015).

Corresponding author - Adres do korespondencji: Marcelina Krupa-Małkiewicz, Department of Plant Genetics, Breeding and Biotechnology, West Pomeranian University of Technology, Szczecin, Juliusza Słowackiego 17, 71-434 Szczecin, Poland, e-mail: mkrupa@zut.edu.pl 
The tissue culture system allows the propagation of selected genotypes with high multiplication rate in an aseptic, temperature-controlled environment (Osman et al. 2013; Tarinejad 2013; Teixeira da Silva et al. 2016). Numerous scientific articles have reported using tissue culture techniques, with many researches successfully applying these to the goji shrub (Kairong et al. 1999; Hu et al. 2001, 2008; Osman et al. 2013; Dănăilă-Guidea et al. 2015). In these studies were used different sources of goji berry explants: shoot tips, nodal segments of leaves, stem axillary buds and roots. In most cases, shoot proliferation was achieved by axillary bud obtained from nodal explants. However, most of these works have no information regarding to the effectiveness of disinfection of the initial material. According to Amiri et al. (2013), Zeng (2014) and Teixeira da Silva et al. (2016) the establishment of an effective tissue culture from plant material derived from greenhouse or field up to the disinfection process. Well-chosen disinfectant allows to maintain a balance between highly effective in disinfecting explants and its high ability for survival and regeneration. In in vitro culture usually chemical disinfectants such as sodium hypochlorite, ethanol, calcium or mercuric chloride, hydrogen peroxide and silver nanoparticles or antibiotics have been used (Amiri et al. 2013; Tarinejad 2013). However, the chemicals used in too high concentrations may be toxic to the plant and to the environment. There is required a specialized utilization of these compounds. An alternative method of disinfection might be the ozonation. Ozone has relatively high solubility in water with a high redox potential and is recently declared Generally Recognized As Safe (GRAS) by an expert panel for use in food processing (Graham 1997). However, to date, it has been used in disinfection of potable water, processing, as well as in stored food (seeds, vegetables, fruits, meat). The aim of the study was to compare the effectiveness of seeds disinfection of two goji berries cultivars, ' $A$ ' and 'New Big' using different solution with disinfection methods used.

\section{MATERIAL AND METHODS}

\section{Plant material}

The experiment was conducted at tissue culture laboratory of the Department of Genetics, Plant Breeding and Biotechnology of West Pomeranian University of Technology in Szczecin.

Seeds of two cultivars 'A' and 'New Big' of goji berry (Lycium barbarum L.) were used as plant material. Goji fruits were obtained after harvest (November) from the experimental orchard of the Pomology Department of West Pomeranian University of Technology in Szczecin.

\section{Disinfestations methods}

Seeds were submerged in $70 \%$ ethanol for $30 \mathrm{~s}$ and after twice washing with sterile deionized water, they were submerged in different disinfecting treatments:

- sodium hypochlorite ( $\mathrm{NaOCl}$ ) in $7 \%, 10 \%$ and $15 \%$ for $15 \mathrm{~min}$;

- $0.2 \%$ mercury chloride $\left(\mathrm{HgCl}_{2}\right)$ for $15 \mathrm{~min}$;

- ozone gas in two times of exposure (5 and $15 \mathrm{~min}$ );

- ozone in water in two times of exposure (5 and 15 minutes).

Ozon was produced by a discharge generator ( $\mathrm{ZYH} 135)$ for $3.5 \mathrm{~g} \cdot \mathrm{h}^{-1}$ capacity with the efficiency of the pump guaranteeing a flow of 15 liters of air within 1 minute.

After the above treatments, seeds were rinse three times with sterile and deionized water for 1, 2 and 5 minutes, respectively under a sterile laminar flow hood. 


\section{Medium and culture condition}

Aseptic, sterilized seeds were placed individually in glass tube with capacity of $35 \times 110 \mathrm{~mm}$ containing $15 \mathrm{~mL}$ of MS medium (Murashige and Skoog 1962) without plant growth regulators. Each combination included one hundred seeds (four replicates of 25 seeds).

Culture medium were supplemented with $8.0 \mathrm{~g} \cdot \mathrm{dm}^{-3}$ agar (Biocorp, Poland), $30 \mathrm{~g} \cdot \mathrm{dm}^{-3}$ sucrose and $100 \mathrm{mg} \cdot \mathrm{dm}^{-3}$ myo-inositol, $\mathrm{pH}$ was adjusted to 5.7 by adding $0.1 \mathrm{M}$ of $\mathrm{NaOH}$ or $\mathrm{HCl}$ and autoclaved at $121^{\circ} \mathrm{C}(0.1 \mathrm{MPa})$ for 19 minutes. The cultures were maintained in a growth room at a temperature of $24 \pm 1^{\circ} \mathrm{C}$ under $16 \mathrm{~h}$ photoperiod under a fluorescent lamp (photosynthetic photon flux density $40 \mu \mathrm{mol} \cdot \mathrm{m}^{-2} \cdot \mathrm{s}^{-1}$ ). Contamination and germination rate were analyzed after 10 days for each combination.

\section{Statistical analysis}

The data were subjected to one-factor variance analysis (ANOVA). Mean comparisons were performed using Tukey's least significant difference (LSD) test; significance was set at $p<0.05$. The percentage data of disinfection methods were transformed before analysis using the Bliss function $y=\operatorname{arc} \sin \sqrt{ } \mathrm{x}$. To determine the relation between the disinfection method the results were subjected to an agglomerative cluster analysis and classified into groups in a hierarchical order by means of the Ward's method. The statistical analyses were performed using the Statistica 12.5 software (StatSoft, Polska).

\section{RESULTS AND DISCUSSION}

Adequately disinfection of components is one of most important ways of controlling contamination in in vitro culture (Amiri et al. 2013). Different explants require different types of compounds, concentrations and exposure periods for the disinfection process to be optimized (Teixeira da Silva et al. 2016). $\mathrm{NaOCl}$ is considered a very effective microbe killer and has been frequently used for surface sterilization of plants for in vitro culture (Bakhsh et al. 2016). While mercuric chloride $\left(\mathrm{HgCl}_{2}\right)$ is extremely toxic to plants and humans and must be carefully disposed (Talei et al. 2011). Ozone is reported to have 1.5 times the oxidizing potential of chlorine and 3000 times the potential of hypochlorus acid (HClO) - Suslow (1998).

In the current study the effectiveness of seeds sterilization depend on the disinfection solution used and its concentration. It was observed that goji seeds submerged in $15 \% \mathrm{NaOCl}$ solution indicated the lowest number of contamination as well as germination ability (Table 1). However, when $7 \%$ solution of $\mathrm{NaOCl}$ was used for disinfection, the percentage of germinated goji ' $A$ ' and 'New Big' seeds was the highest (62\% and $78 \%$, respectively) (Table 2). As compared to $\mathrm{NaOCl}$ disinfection of seeds with $0.2 \% \mathrm{HgCl}_{2}$ was less effective mainly to 'New Big'. The percent of infected goji seeds of 'A' and 'New Big' was higher (17\% and 10\%, respectively) (Table 1). Furthermore, $\mathrm{HgCl}_{2}$ solution was more toxic and inhibited the germination of goji seeds, which was $37 \%$ for cultivar 'A' and $30 \%$ for 'New Big' cultivars (Table 2). It was observed that $\mathrm{O}_{3}$ in water and $\mathrm{O}_{3}$ gas affected seeds ability to germination (Table 3 ). The highest number $(87 \%)$ of uncontaminated explants that did not developed shoots was noticed after disinfection of goji 'New Big' explants using $\mathrm{O}_{3}$ in water for 5 minutes and $\mathrm{O}_{3}$ gas for 15 minutes. Comparing ozonation method for disinfection of goji seeds, it was observed that the best results were obtained when $\mathrm{O}_{3}$ in water for 15 minutes was used when the percentage of germination was the highest ('A' - 47\% and 'New Big' - 53\%) (Table 2), and the efficiency of sterilization of goji seeds in 'A' cultivar was $100 \%$ (Table1). 
Table 1. The percentage of contaminated goji ' $A$ ' and 'New Big' explants according to disinfection method used

Tabela 1. Procent zakażonych eksplantatów goji odmian 'A' i ‘New Big' w zależności od zastosowanego środka dezynfekującego

\begin{tabular}{lcccc}
\hline \multicolumn{1}{c}{$\begin{array}{c}\text { Disinfection method } \\
\text { Metody dezynfekcji }\end{array}$} & \multicolumn{3}{c}{ Cultivar - Odmiana } \\
\cline { 2 - 5 } & $5 \mathrm{~min}$ & 'A' & 'New Big' & $\begin{array}{c}\text { Mean } \\
\text { Srednia }\end{array}$ \\
\hline $\begin{array}{l}\text { Ozone gas } \\
\text { Ozonowanie } \\
\text { na sucho }\end{array}$ & $15 \mathrm{~min}$ & $7 \mathrm{~b}$ & $40 \mathrm{~d}$ & $23.5 \mathrm{c}$ \\
\hline $\begin{array}{l}\text { Ozon in water } \\
\text { Ozonowanie } \\
\text { w wodzie }\end{array}$ & $5 \mathrm{~min}$ & $20 \mathrm{c}$ & $0 \mathrm{a}$ & $3.5 \mathrm{a}$ \\
\hline & $15 \mathrm{~min}$ & $0 \mathrm{a}$ & $0 \mathrm{a}$ & $10 \mathrm{ab}$ \\
$\mathrm{nyyyy} \mathrm{NaOCl}$ & $7 \%$ & $8 \mathrm{~b}$ & $7 \mathrm{~b}$ & $3.5 \mathrm{a}$ \\
\hline & $10 \%$ & $7 \mathrm{~b}$ & $14 \mathrm{c}$ & $5 \mathrm{~b}$ \\
\hline & $15 \%$ & $4 \mathrm{ab}$ & $3 \mathrm{a}$ & $3 \mathrm{a}$ \\
\hline
\end{tabular}

Means in the same column followed by the same letter are not significantly different at $\alpha<0.05$ according to Tukey test - Średnie w kolumnach oznaczone tymi samymi literami alfabetu nie różnią się według testu Tukeya na poziomie istotności $\alpha<0,05$.

Table 2. The percentage of uncontaminated goji 'A' and 'New Big' explants that germinated according to disinfection method used

Tabela 2. Procent niezakażonych eksplantatów goji odmian 'A' i 'New Big', które skiełkowały, w zależności od zastosowanego środka dezynfekującego

\begin{tabular}{lcccc}
\hline & \multicolumn{1}{c}{$\begin{array}{c}\text { Disinfection method } \\
\text { Metody dezynfekcji }\end{array}$} & Cultivar - Odmiana & Mean \\
\cline { 2 - 5 } & $5 \mathrm{~min}$ & $33 \mathrm{~b}$ & 'New Big' & Średnia \\
\hline $\begin{array}{l}\text { Ozone gas } \\
\text { Ozonowanie } \\
\text { na sucho }\end{array}$ & $15 \mathrm{~min}$ & $40 \mathrm{bc}$ & $47 \mathrm{c}$ & $40 \mathrm{~cd}$ \\
\hline $\begin{array}{l}\text { Ozon in water } \\
\text { Ozonowanie } \\
\text { w wodzie }\end{array}$ & $5 \mathrm{~min}$ & $7 \mathrm{a}$ & $7 \mathrm{a}$ & $23.5 \mathrm{ab}$ \\
\hline \multirow{2}{*}{$\mathrm{NaOCl}$} & $15 \mathrm{~min}$ & $47 \mathrm{c}$ & $13 \mathrm{a}$ & $10 \mathrm{a}$ \\
\hline & $7 \%$ & $62 \mathrm{~d}$ & $53 \mathrm{c}$ & $50 \mathrm{~d}$ \\
\hline & $10 \%$ & $47 \mathrm{c}$ & $78 \mathrm{~d}$ & $70 \mathrm{e}$ \\
\hline & $15 \%$ & $38 \mathrm{~b}$ & $47 \mathrm{c}$ & $47 \mathrm{~d}$ \\
\hline
\end{tabular}

Explanations see Table 1 - Objaśnienia zob. tab. 1.

Table 3. The percentage of uncontaminated goji 'A' and 'New Big' explants that did not germinated according to disinfection method used

Tabela 3. Procent niezakażonych eksplantatów goji odmian 'A' i 'New Big', które nie skiełkowały, w zależności od zastosowanego środka dezynfekującego

\begin{tabular}{lcccc}
\hline \multicolumn{1}{c}{$\begin{array}{c}\text { Disinfection method } \\
\text { Metody dezynfekcji }\end{array}$} & \multicolumn{3}{c}{ Cultivar - Odmiana } \\
\cline { 2 - 5 } & $5 \mathrm{~min}$ & $53 \mathrm{~b}$ & 'New Big' & $\begin{array}{c}\text { Mean } \\
\text { Srednia }\end{array}$ \\
\hline $\begin{array}{l}\text { Ozone gas } \\
\text { Ozonowanie } \\
\text { na sucho }\end{array}$ & $15 \mathrm{~min}$ & $53 \mathrm{~b}$ & $0 \mathrm{a}$ & $26.5 \mathrm{a}$ \\
\hline $\begin{array}{l}\text { Ozon in water } \\
\text { Ozonowanie } \\
\text { w wodzie }\end{array}$ & $5 \mathrm{~min}$ & $67 \mathrm{~d}$ & $87 \mathrm{e}$ & $70 \mathrm{e}$ \\
\hline & $15 \mathrm{~min}$ & $53 \mathrm{bc}$ & $87 \mathrm{e}$ & $77 \mathrm{e}$ \\
$\mathrm{nyyyy} \mathrm{NaOCl}$ & $7 \%$ & $30 \mathrm{a}$ & $33 \mathrm{~cd}$ & $43 \mathrm{~cd}$ \\
\hline & $10 \%$ & $47 \mathrm{~b}$ & $44 \mathrm{~d}$ & $37 \mathrm{bc}$ \\
\hline & $15 \%$ & $60 \mathrm{~cd}$ & $17 \mathrm{~b}$ & $32 \mathrm{~b}$ \\
\hline
\end{tabular}

Explanations see Table 1 - Objaśnienia zob. tab. 1. 
According to many authors (Teixeira et al. 2006; Tiwari et al. 2012; Amiri et al. 2013; Teixeira da Silva et al. 2016) disinfection solution of sodium hypochlorite and mercury chloride played an important role in the contamination control. Hu et al. (2001) applied $0.1 \% \mathrm{HgCl}_{2}$ for 6 minutes followed by three washes with sterile water for disinfection of $L$. barbarum. Then seeds were imbibed in sterile water for $6 \mathrm{~h}$ at room temperature and next were sterilized a second time for 8 minutes in $0.1 \% \mathrm{HgCl}_{2}$. While, seeds of $L$. barbarum cultivar 'Ningji No.1' were surface-sterilize in $70 \%$ ethanol (30-40 s) and after that they were submerged in $0.1 \%$ $\mathrm{HgCl}_{2}$ for 8-10 minutes, followed by 5 rinses with sterile distilled water (Hu et al. 2008). Another disinfection method of goji seeds applied Dănăilă-Guidea et al. (2015) using commercial bleach (ACE) containing 4.85\% sodium hypochlorite for 10 minutes and a dilute bleach product concentration trading $4.50 \%$ sodium hypochlorite for 20 minutes, followed by three washes with sterile distilled water. Similarly, Osman et al. (2013) for disinfection of goji seeds, obtained from dried fruits, applied sodium hypochlorite (no report of concentration) with two drops of Tween 20, followed by subsequent three time rinsing procedures with sterile distilled water. However, these work do not describe the effectiveness of disinfection method on the germination rate of goji seeds.

Alternative techniques have been appreciated because all of these disinfectants may be toxic for plant tissue and environment. One of an alternative method might be disinfection with ozone. However, there are a low number of reports about the effect of ozone disinfection in in vitro culture. Much more likely is described ozone to be used in food processing and for storage of vegetables and fruits. Tiwari et al. (2010) demonstrated that ozone which is natural agent, may offer unique advantage for grain processing along with addressing growing concerns over the use of harmful pesticides. Nowakowicz-Dębek et al. (2013) treated wheat grains with ozone produced by an ozone generator of $100 \mathrm{mg} \cdot \mathrm{h}^{-1}$ capacity for $0,0.5,1,3,6$ and $9 \mathrm{~h}$. They observed that the exposure to ozone over longer period of time caused higher mold fungal reducibility. Krupa-Małkiewicz et al. (in press) compare the effectiveness of $7 \%$ and $10 \% \mathrm{NaOCl}$ with ozone gas and ozone in water for disinfection of different seeds in in vitro culture. These have fund that ozone treatment of seeds gives good results, as in the case of using $7 \% \mathrm{NaOCl}$.

In the present study, goji seed contaminations under the different sterilization procedures varied from 0 to $40 \%$. Analysis of the percentage of germinated seeds and their infections for both goji cultivars, carried out according to Ward's method, divided into four groups according to the similarity of their actions: $\mathrm{A}-7 \%$ and $10 \% \mathrm{NaOCl}, \mathrm{B}-0.2 \% \mathrm{HgCl}_{2}, \mathrm{C}-15 \% \mathrm{NaOCl}$, 5 minutes $\mathrm{O}_{3}$ gas and 15 minutes $\mathrm{O}_{3}$ in water, $\mathrm{D}-5$ minutes $\mathrm{O}_{3}$ in water and 15 minutes $\mathrm{O}_{3}$ gas (Fig. 1). The results obtained in this study, demonstrated that the seeds cultured after $\mathrm{O}_{3}$ treatment are characterized by a similar effectiveness of disinfection and germination as when applying $15 \% \mathrm{NaOCl}$. Therefore, ozone gas makes an alternative for commonly used disinfectants. Ozone rapidly attacks bacterial cell walls and is more effective against the thick-walled spores of plant pathogens than chlorine, at practical and safe concentrations (Suslow 1998). 


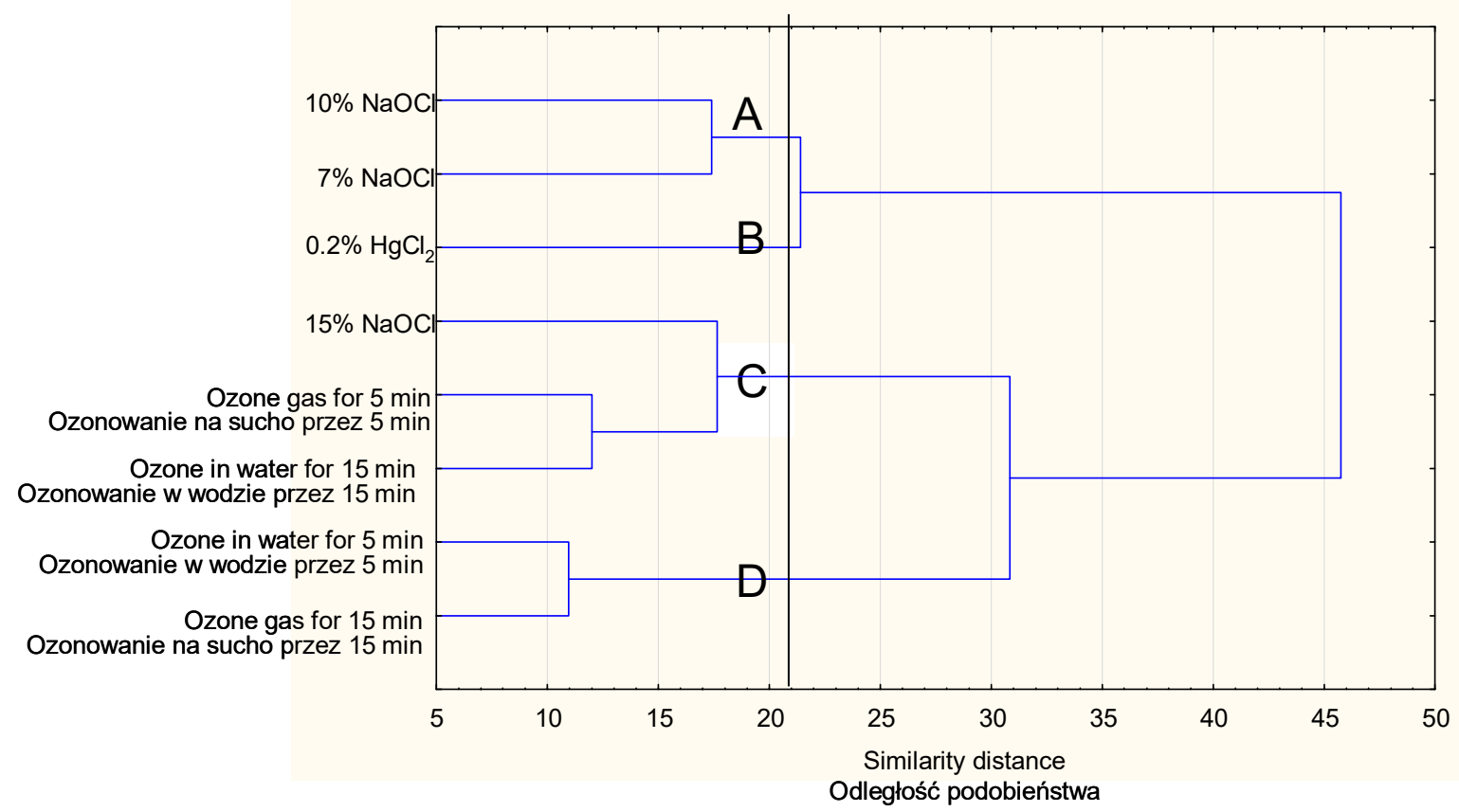

Fig. 1. Similarity distance between disinfection method use

Ryc. 1. Odległość podobieństwa pomiędzy zastosowanymi metodami dezynfekcji

\section{CONCLUSIONS}

The effectiveness of disinfection of explants in in vitro culture depended on many factors. One of them is properly chosen disinfection method. Ozone gas $\left(\mathrm{O}_{3}\right)$ makes an alternative for commonly used disinfectants. The efficacy of ozone was similar to sodium hypochlorite which it is less toxic to the plants and the environment. However, it requires further researches to evaluate the optimum conditions for disinfections of explants in in vitro culture. Therefore, use of ozone gas as a natural disinfectant is considered a very effective microbe killer and is used frequently for surface disinfection.

\section{REFERENCES}

Amiri S., Ashtari S., Babaiy A.H., Nazari S.A., Khodadadi E., Khodadadi E., Sabzi M. 2013. Control of contamination during micropropagation process of Rootstocks Mariana (Prunus mariana). Ann. Biol. Res. 4(3), 149-151.

Bakhsh A., Anayol E., Sancak C., Özcan S. 2016. An efficient and cost effective sterilizing method with least microbial contamination and maximum germination ratio for in vitro cotton (Gossypium hirsutum L.) culture. J . Anim. Plant Sci. 26(3), 868-873.

Dănăilă-Guidea A.M., Dobrinoiu R-V., Vişan L., Toma R.C. 2015. Protocol for efficient in vitro multiplication of Lycium barbarum L. (Goji) by direct organogenesis. Sci. Bull., Ser. F Biotechnologies 19, 34-38.

Graham D.M. 1997. Use of ozone for food-processing. Food Techn. 51, 72-75.

Hu Z., Guo G.Q., Zhao D.L., Li L.H., Zheng G.C. 2001. Shoot regeneration from leaf explant of Lycium barbarum and Agrobacterium-mediated genetic transformation. Russ. J. Plant Pysiol. 48, 453-458.

Hu Z., Hu Y., Gao H.H., Guan X.Q., Zhuang D.H. 2008. Callus production, somatic emryogenesis and plant regeneration of Lycium barbarum root explants. Biol. Plant. 52(1), 93-96. 
Kairong C., Gengsheng X., Xinmin L., Gengmei X., Yafu W. 1999. Effect of hydrogen peroxide on somatic embryogenesis of Lycium barbarum L. Plant Sci. 146, 9-16.

Krupa-Małkiewicz M., Kruczek A., Ochmian I. 2017. Comparison of efficacy of $\mathrm{NaOCl}$ and ozonation in the process of disinfection of seed in in vitro cultures. [in press]

Murashige T.M., Skoog F. 1962. A revised medium for rapid growth and bioassays with tobacco tissue cultures. Physiol Plant. 15, 473-497.

Nowakowicz-Dębek B., Bojarczyk M., Krukowski H., Misztal-Majewska B., Wlazło Ł., Trawińska B. 2013. Ozone disinfection of feed wheat. Ann. UMCS Lub. 31(1), 43-48.

Osman N.I., Awal A., Sidik N.J., Abdullah S. 2013. Callus induction and somatic embryogenesis from leaf and nodal explants of Lycium barbarum L. (Goji). Biotechnology 12(1), 36-45.

Suslow T. 1998. Basics of ozone applications for postharvest treatment of fruits and vegetables. Perish. Hand. Quart. 94, 9-11.

Talei D., Saad M.S., Yusop M.K., Mihdzar A.K., Valdiani A. 2011. Effect of different surface sterilizers on seed germination and contamination of King of Bitters (Andrographis paniculata Nees.) Am. Euras. J. Agric. Environ. Sci. 10, 639-643.

Tarinejad A. 2013. Effects of disinfectants and antibiotics on contamination during propagation of walnut (Juglans regia L.). Res. Crops. 14(1), 219-225.

Teixeira S.L., Ribeiro J.M., Teixeira M.T. 2006. Influence of $\mathrm{NaClO}$ on nutrient medium sterilization and on pineapple (Ananas comosus cv Smooth cayenne) behavior. Plant Cell. Tiss. Organ Cult. 86, 375-378.

Teixeira da Silva J.A., Winarto B., Dobránszki J., Cardoso J.C., Zeng S. 2016. Tissue disinfection for preparation of Dendrobium in vitro culture. Folia Hort. 28(1), 57-75.

Tiwari B.K., Brennan C.S., Curran T., Gallagher E., Cullen P.J., O’Donnell C.P. 2010. Application of ozone in grain processing. J. Cereal Sci. 51, 248-255.

Tiwari A.K., Tripathi S., Lal M., Mishra S. 2012. Screening of some chemical disinfectants for media sterilization during in vitro micropropagation of sugarcane. Sugar Tech. 14(4), 364-369.

Zeng Y. 2014. Optimization of the method to obtain effective sterile explants in tissue culture of Ardisia mamillata Hence. Agricult. Sci. Tech. 15(6), 917-936.

Abstract. Using disinfectant components is one of main ways to control of fungal and bacterial contaminations in the in vitro culture. Alternative to commonly used chemicals is ozonation. The present study was focused on the efficiency of seeds disinfection of two goji cultivars ' $A$ ' and 'New Big' using eight different treatments, $7 \%, 10 \%$ and $15 \% \mathrm{NaOCl}$ and $0.2 \% \mathrm{HgCl}_{2}$ for 15 minutes each, $\mathrm{O}_{3}$ gas and $\mathrm{O}_{3}$ in water for 5 and 15 minutes. The highest percentage of germinated seeds of ' $A$ ' and 'New Big' (respectively $62 \%$ and $78 \%$ ) with the lowest number of infections (respectively $8 \%$ and $14 \%$ ) was obtained after using $7 \% \mathrm{NaOCl}$ solution. Less effective was $0.2 \% \mathrm{HgCl}_{2}$ solution, where the percentage of germinated seeds of ' $A$ ' and 'New Big' was lower (respectively $37 \%$ and $30 \%$ ). However, after $\mathrm{O}_{3}$ in water treatment of goji ' $A$ ' and 'New Big' for 15 minutes the percentage of germinated seeds was the highest (respectively $47 \%$, and $53 \%$ ) and sterility of the cultures of goji ' $A$ ' was $100 \%$. In addition to, the ozonation of the seeds showed similar disinfection efficiency, as with $15 \% \mathrm{NaOCl}$ solution. Therefore, ozone gas makes an alternative for commonly used disinfectants. 
